\title{
Analisis Keterampilan Proses Sains Mahasiswa Calon Guru Fisika pada Praktikum Fisika Dasar
}

\author{
Arie Arma Arsyad ${ }^{*}$, Dewi Sartika ${ }^{2}$ \\ 1. Program Studi Pendidikan IPA, Universitas Negeri Makassar \\ 2. Program Studi Pendidikan Fisika, Universitas Sulawesi Barat \\ *e-mail: ariearmaarsyad@unm.ac.id
}

\begin{abstract}
Abstrak
Keterampilan proses sains adalah salah satu keterampilan yang perlu dimiliki oleh mahasiswa pendidikan fisika. Tujuan penelitian ini adalah untuk mendeskripsikan keterampilan proses sains yang dimiliki oleh mahasiswa pendidikan fisika. Metode penelitian yang digunakan adalah metode kuantitatif deskriptif dengan analisis data secara induktif. Subjek penelitian ini adalah mahasiswa semester 1 yang memprogramkan mata kuliah fisika dasar 1. Data yang diperoleh melalui tes tertulis. Hasil penelitian yang diperoleh adalah keterampilan proses sains yang dimiliki oleh mahasiswa meningkat dengan peningkatan sebesar 0,79. Peningkatan ini termasuk kategori tinggi
\end{abstract}

Kata Kunci: Analisis Keterampilan Proses Sains, Mahasiswa, Praktikum Fisika Dasar

\begin{abstract}
Science process skills are one of the skills that physics education students need to have. The aim of this study was to describe the science process skills possessed by prospective physics teacher. The research method used is descriptive quantitative method with inductive data analysis. The subjects of this study were freshmen programming basic physics practicum 1. Data obtained through written tests. The results obtained were the process skills possessed by students increased by 0.79 . This increase was in the high category.
\end{abstract}

Keywords: Analysis of Scince Process Skills, Students, Basic Physics Practicum

\section{PENDAHULUAN}

Praktikum fisika dasar adalah salah satu mata kuliah wajib yang harus diprogramkan oleh mahasiswa di Program Studi Pendidikan Fisika Universitas Sulawesi Barat. Kegiatan praktikum memerlukan keterampilan proses sains seperti merumuskan masalah, merumuskan hipotesis, mengidentifikasi dan mendefinisikan variabel, menganalisis data, dan menarik kesimpulan. Menurut Semiawan (dalam Misbah, 2018), keterampilan proses sains sangat penting dikuasai karena akan jauh lebih dalam memahami konsep abstrak dengan belajar langsung melakukan sendiri.

Hasil pengamatan yang dilakukan dalam kegiatan praktikum pengantar laboratorium fisika didapatkan bahwa mahasiswa yang mengikuti kegiatan praktikum tersebut pada umumnya belum mengenal aspek-aspek keterampilan proses sains. Sehingga keterampilan mahasiswa di aspek psikomotorik rendah dibandingkan dengan kognitifnya. Hal ini terbukti pada kegiatan merangka rangkaian listrik sederhana, mahasiswa masih kesulitan walaupun telah menerima materi tersebut selama kegiatan perkuliahan. 
Menurut Hadiya (2018), terdapat 7 aspek dasar keterampilan proses sains yaitu: 1) mengidentifikasi variabel, 2) mengungkapkan pengertian variabel, 3) menginterpretasi data, 4) menghubungkan antar data, 5) memformulasikan model, 6) menarik kesimpulan, dan 7) menyataakan praduga sementara. Keterampilan proses sains sangat diperlukan bagi seorang mahasiswa untuk menyiapkan diri menghadapi tantangan masa depan yang semakin berat. Para mahasiswa dituntut untuk memiliki berbagai keterampilan untuk mendapatkan pekerjaan yang layak.

Berdasarkan uraian di atas, peneliti menganalisis suatu keterampilan yaitu keterampilan proses sains yang dimiliki setelah diterapkan suatu model pembelajaran yang mendukung keterampilan tersebut dapat ditingkatkan.

\section{Metode}

Jenis penelitian adalah penelitian deskriptif yang bertujuan untuk menggambarkan keterampilan proses sains yang dimiliki oleh subjek penelitian. Subjek dalam penelitian ini adalah mahasiswa Program Studi Pendidikan Fisika semester 1 dalam mata kuliah praktikum fisika dasar 1 yang berjumlah 18 mahasiswa. Teknik pengumpulan data keterampilan proses sains diperoleh melalui pemberian tes di akhir pembelajaran. Pada soal keterampilan proses sains, mahasiswa dituntut untuk mengemukakan alasan mengapa memilih jawaban tersebut sehingga dapat meminimalisir terjadinya jawaban asal tebak. Selanjutnya menghitung nilai untuk setiap indikator keterampilan proses sains dengan menggunakan rumus:

$$
\text { Nilai }=\frac{\text { skor yang diperoleh }}{\text { skor maksimal }} \times 100
$$

Kemudian menggunakan persamaan n-gain yang menunjukkan peningkatan keterampilan proses sains berdasarkan representasi fisika mahasiswa sebelum dan sesudah perlakuan yang kemudian dikonversi dengan kriteria sebagai berikut.

Tabel 1 Kriteria n-gain

\begin{tabular}{cc}
\hline Skor N-Gain & Kriteria \\
\hline $0.70<$ n-gain & Tinggi \\
$0.30 \leq$ n-gain $\leq 0.70$ & Sedang \\
n-gain $<0.30$ & Rendah
\end{tabular}

\section{Hasil}

Tabel 2 Peningkatan keterampilan proses sains

\begin{tabular}{|c|c|c|c|c|c|}
\hline \multirow{2}{*}{ No. } & \multirow{2}{*}{$\begin{array}{l}\text { Indikator } \quad \text { Keterampilan } \\
\text { Proses Sains (Skor Maksimal) }\end{array}$} & \multicolumn{2}{|c|}{ Rerata Nilai } & \multirow{2}{*}{$N$-gain } & \multirow{2}{*}{ Keterangan } \\
\hline & & 01 & $\mathbf{O 2}$ & & \\
\hline 1 & TP $01(10)$ & 50 & 100 & 1.00 & Tinggi \\
\hline 2 & TP 02 (10) & 10 & 100 & 1.00 & Tinggi \\
\hline 3 & ТP 03a (7) & 43 & 100 & 1.00 & Tinggi \\
\hline
\end{tabular}




\begin{tabular}{llllll}
4 & TP 03b (7) & 0 & 43 & 0.43 & Sedang \\
5 & TP 03c (7) & 14 & 100 & 1.00 & Tinggi \\
6 & TP 03d (7) & 14 & 71 & 0.67 & Sedang \\
7 & TP 03e (7) & 0 & 71 & 0.71 & Tinggi \\
8 & TP 04 (15) & 0 & 50 & 0.50 & Sedang \\
9 & TP 05 (15) & 0 & 60 & 0.60 & Sedang \\
10 & TP 06 (10) & 0 & 100 & 1.00 & Tinggi \\
\multicolumn{2}{l}{ Rata-rata } & & & 0.79 & Tinggi \\
\hline
\end{tabular}

Keterangan Tujuan Pembelajaran

1. Merumuskan masalah

2. Merumuskan hipótesis

3a. Mengidentifikasi variabel manipulasi

3b. Mendefinisikan operasional variabel manipulasi

3c. Mengidentifikasi variabel respon

3d. Mendefinisikan operasional variabel respon

3e. Mengidentifikasi variabel $k$ ontrol

4. Merancang tabel data hasil pengamatan

5a. Membuat solusi dari data yang diberikan

5b. menganalisis data

6. Menyimpulkan hasil eksperimen

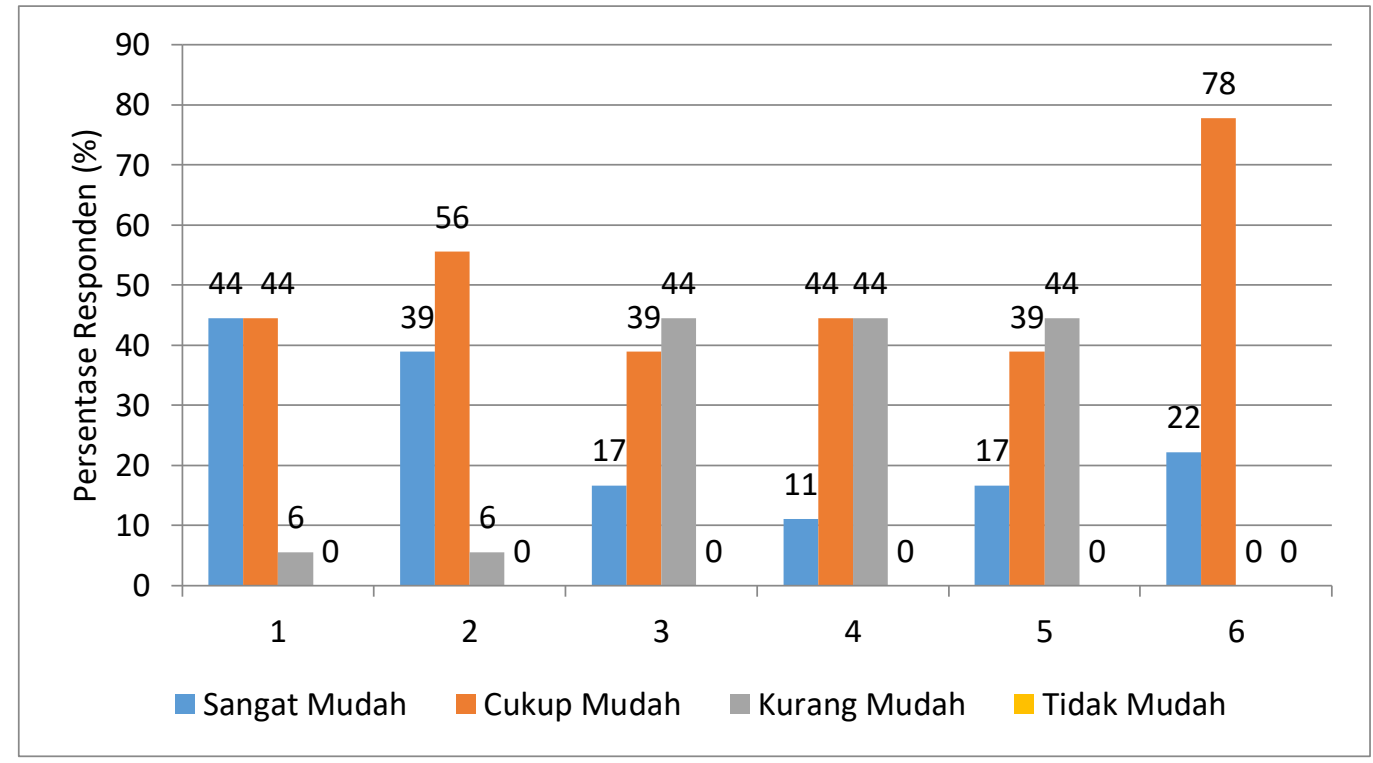

\section{Gambar 1 Respon mahasiswa terhadap komponen keterampilan proses sains}

Keterangan Tujuan Pembelajaran

1. Merumuskan masalah

2. Merumuskan hipótesis

3. Mengidentifikasi dan mendefinisikan variabel

4. Merancang tabel data hasil pengamatan

5. menganalisis data

6. Menyimpulkan hasil eksperimen 


\section{Pembahasan}

Berdasarkan Tabel 2 mengindikasikan bahwa mahasiswa memiliki kecepatan belajar yang berbeda-beda dalam membangun pengetahuan sehingga memerlukan tambahan waktu, bimbingan, atau cara lain dalam belajar untuk menguasai suatu konsep atau materi. Rata-rata peningkatan keterampilan proses sains menunjukkan angka sebesar 0,79 yang berada pada kategori tinggi. Hal ini terjadi karena dalam pembelajaran menggunakan model kooperatif yang memfasilitasi mahasiswa sebagai contoh kemampuan membuat kesimpulan yang dilatihkan melalui fasilitas LKM. Artinya mahasiswa benar-benar dilatih untuk menyimpulkan dan dituliskan dalam LKM. Temuan ini sesuai dengan pendapat Solomom dalam Hanze (2007) yang menyatakan bahwa "positive effects of cooperative learning on interpersonal attitudes, behaviours, and skills." Kemudian ditambahkan pula oleh Gupta (2004) bahwa cooperative learning offered many benefits to students in terms of graduate attributes such as teamwork, communication, lifelong learning, and problem solving." Di mana pembelajaran kooperatif memberikan dampak positif untuk para siswa seperti kerja sama, berkomunikasi, pembelajaran sepanjang hayat, dan problem solving. Hal sama juga ditemukan dikemukakan oleh Barczi (2013) yang menyatakan bahwa "cooperative learning can be considered to be an effective tool for developing problem solving skills," Hal ini mengindikasikan bahwa pembelajaran kooperatif dapat meningkatkan keterampilan di mana keterampilan yang dilatihkan pada pembelajaran ini adalah keterampilan problem solving.

Pada Tabel 2, terdapat 6 indikator keterampilan proses sains yang berada pada kategori tinggi dari 10 tujuan pembelajaran keterampilan proses sains. Pada saat pretest keterampilan proses sains meliputi merumuskan masalah, merumuskan hipotesis, mengidentifikasi variabel, mendefinisikan operasional variabel, merancang tabel hasil pengamatan, menganalisis data, dan menarik kesimpulan tidak terdapat siswa satupun yang mendapat skor maksimal dari setiap indikator. Setelah dilaksanakan pembelajaran, indikator keterampilan proses sains yang berada pada kategori sedang adalah tujuan pembelajaran ke-4, tujuan pembelajaran ke-6, tujuan pembelajaran ke-8, dan tujuan pembelajaran ke-9. Pada tujuan pembelajaran ke-4 dan tujuan pembelajaran ke-6, siswa belum bisa mendefinisikan secara operasional variabel manipulasi dan variabel respon. Pada tujuan pembelajaran ke-8 dan tujuan pembelajaran ke-9, terdapat ketidaksesuaian jawaban antara tabel dengan analisis jawaban yang siswa berikan.

Faktor pendukung lainnya yang menyebabkan terdapat beberapa indikator keterampilan proses sains yang berada pada kategori sedang adalah frekuensi pertemuan pembelajaran yang dilakukan hanya empat kali pertemuan, padahal untuk mampu melatihkan keterampilan proses sains perlu beberapa kali pertemuan dalam pembelajaran bahkan memerlukan waktu yang panjang sehingga memberikan kesempatan kepada siswa untuk senantiasa terlatih dengan pertanyaan-pertanyaan dari guru yang sifatnya menantang siswa untuk mengemukakan gagasannya sendiri. Hal ini sejalan dengan teori Vygotsky (dalam Rahmawati, 2012: 146) bahwa pendidik harus mencoba untuk membantu peserta didik terlibat dalam pemikiran tingkat yang lebih tinggi melalui bantuan terstruktur telah semakin diterima dalam dekade ini.

Dalam pembelajaran yang telah dilakukan, peneliti menemukan bahwa untuk melatihkan keterampilan proses sains, siswa membutuhkan bimbingan yang lebih intensif, di antaranya dalam proses mengidentifikasi dan mendefinisikan tiap variabel dan merancang tabel 
pengamatan berdasarkan data yang diperoleh. Hal ini terlihat bahwa siswa selalu bertanya dan membutuhkan bimbingan guru ketika proses pembelajaran dilakukan. Berdasarkan hasil tes keterampilan proses sains juga menunjukkan apa yang telah diajarkan dan dilatih belum sepenuhnya dipahami, terlihat dari n-gain tujuan pembelajaran ketiga yaitu mendefinisikan operasional variabel khususnya variabel respon, menentukan variabel kontrol dan merancang tabel hasil pengamatan meningkat secara signifikan.

Dalam implementasi pembelajaran yang telah dilakukan di kelas ditemukan beberapa kendala. Kendala yang ditemukan di lapangan di antaranya adalah:

a. Semua mahasiswa belum tahu mengenai keterampilan proses sains.

b. Mahasiswa belum pernah mendapat pembelajaran model proses sains.

c. Mahasiswa belum bisa mengerjakan LKM model keterampilan proses sains.

Kendala-kendala tersebut mengakibatkan pembelajaran berlangsung lebih lambat dari waktu yang telah ditetapkan dalam pembelajaran. Mahasiswa banyak bertanya tentang keterampilan proses sains. Banyak mahasiswa yang belum mengenal istilah-istilah keterampilan proses sains sebagaimana yang tercantum dalam LKM. Oleh karena itu untuk menerapkan pembelajaran ini disarankan agar dosen untuk menjelaskan mengenai istilahistilah yang ada pada keterampilan proses sains sebelum pembelajaran dilakukan.

Dalam proses pembelajaran yang telah dilakukan, peneliti menemukan bahwa untuk melatih keterampilan proses sains, mahasiswa membutuhkan bimbingan yang lebih intensif, khususnya dalam proses merumuskan masalah, merumuskan hipotesis, menuliskan variabel manipulasi, respon, dan kontrol, mendefinisikan operasional variabel, melaksanakan percobaan, mengumpulkan data, menganalisis data, dan menyimpulkan data. Berdasarkan hasil tes keterampilan proses sains masih terdapat $11 \%$ mahasiswa yang kesulitan dalam merumuskan masalah, ada 6\% siswa yang masih sulit merumuskan hipotesis dan menentukan variabel kontrol dari percobaan, dan, masih terdapat $78 \%$ siswa yang masih tidak melengkapi data pada tabel pengamatan. Hal ini disebabkan karena mereka hanya sekedar mengisi tabel pengamatan saja.

\section{Kesimpulan}

Berdasarkan data dan hasil analisis diperoleh kesimpulan bahwa pembelajaran yang dilakukan dapat meningkatan keterampilan proses sains mahasiswa calon guru fisika dengan besar peningkatan 0,79 yang termasuk kategori tinggi.

\section{Referensi}

Barczi, Kriztina. (2013). “Applying Cooperaive Techniques in Teaching Problem Solving”. CEPS Journal 3. Pp. 61-78.

Gupta, Madan L. (2004). "Enhancing Student Performance Through Cooperative Learning in Physical Sciences". Assessment and Evaluation in Higher Education. Vol. 29 No. 1 Feb 2004. Pp. 63-73.. (2004)

Hadiya, Izkar. (2018). Analisis Keterampilan Proses Sains Mahasiswa Pendidikan Fisika dalam Merangkai Rangkaian Elektronika Sederhana. Jurnal Relativitas Vol. 1 No. 1 Oktober 2018 Pg 9-22. 
Hanze, M \& Roland B. (2007). "Cooperative Learning, Motivational Effects, and Student Characteristics: An Experimental Study Comparing Cooperative Learning and Direct Instruction in 12th Grade Physics Classes". Learning and Instruction $17 \mathrm{Pg}$ 29-41

Misbah, Mustika Wati, M. Feyzar Rif'at, dan Miranti Diah Prastika. (2018). Pengembangan Petunjuk Praktikum Fisika Dasar I Berbasis 5 M untuk Melatih Keterampilan Proses Sains dan Pendidikan Karakter Wasaka. Jurnal Fisika FLUX Vol. 15 No. 1 2018. DOI: http://dx.doi.org/10.20527/flux.v15i1.4480

Rahmawati. (2012). Pengembangan Perangkat Pembelajaran dengan Metode Pembelajaran Penemuan Terbmbing (Guided Discovery Learning) untuk Melatih Keterampilan Berpikir Kritis pada Siswa SMP. Surabaya: Universitas Negeri Surabaya. Tesis tidak dipublikasikan 